\title{
RESPON BEBERAPA KOMODITAS SAYURAN (TOMAT, CABAI RAWIT, DAN KETIMUN) TERHADAP KOMBINASI PEMBERIAN BOKASHI DAN AIR LIMBAH CUCIAN BERAS
}

\author{
The Response of Several Crop Commodities (Tomato, Red Pepper, and \\ Cucumber) on The Combination of Bokashi and Rice Extract Applications
}

\author{
Marianne Reynelda Mamondol ${ }^{1)}$ \\ Erson Roby Tungka ${ }^{2)}$ \\ e-mail : mariannemamondol@ymail.com \\ 1)2) Fakultas Pertanian Universitas Kristen Tentena
}

\begin{abstract}
The purposes of this research are to find out the differences of tomato, red pepper, and cucumber productions based on the differences of applied liquid fertilizer concentration and bokashi dosage as well as the interaction between bokashi dosage and liquid fertilizer concentration on the productions those crops. This research uses 6 bokashi dosage treatments, i.e. $\mathrm{B}_{0}$ (without bokashi application), $B_{1}(100 \mathrm{gr}), B_{2}(200 \mathrm{gr}), B_{3}(300 \mathrm{gr}), B_{4}(400 \mathrm{gr})$, and $B_{5}(500 \mathrm{gr})$. The concentration of rice extract liquid fertilizer consists of 5 treatments, i.e. $\mathrm{PC}_{0}$ (without liquid fertilizer application), $\mathrm{PC}_{1}(25 \mathrm{ml}), \mathrm{PC}_{2}(50 \mathrm{ml}), \mathrm{PC}_{3}(75 \mathrm{ml})$, and $\mathrm{PC}_{4}(100 \mathrm{ml})$. There are 30 treatment combinations which every treatment is duplicated twice, so 60 experiment units on every crop commodity are obtained. Therefore, from 3 kinds of crops there are totally 180 experiment units. Data is analyzed using two way anova method and continued with t test for 2 independent samples to find out treatments which differ significantly one and another. Result demonstrates that the application of liquid fertilizer gives significant effect on the productions of red pepper and cucumber. The concentration of $25 \mathrm{ml}$ per crop gives the highest production average, however the increasing of concentration above $25 \mathrm{ml}$ will reduce crop yield. The application of bokashi has significant effect on the productions of all three crops. On tomato and cucumber, the dosage of $500 \mathrm{gr}$ per crop results the highest production average, whereas on tomato, the highest production is observed on the dosage of $200 \mathrm{gr}$. The addition of dosage above $200 \mathrm{gr}$ decreases crop yield. There is negative interaction between the applications of bokashi and liquid fertilizer on the production of cucumber crop. The increasing of bokashi dosage causes augmentation on crop production, but the addition of liquid fertilizer concentration reduces the production. Study conclusion is that tomato, red pepper, and cucumber show different responses on the application of bokashi and rice extract liquid fertilizer.
\end{abstract}

Keywords : Bokashi, liquid fertilizer, interaction, significant effect

\section{PENDAHULUAN}

Sayuran merupakan golongan bahan pangan yang menyediakan berbagai zat gizi melalui makanan yang dikonsumsi manusia. Konsumsi sayuran secara berimbang dalam menu harian dapat memenuhi kebutuhan nutrisi bagi tubuh, yang memungkinkan manusia memperoleh energi guna mempertahankan kerja berbagai organ tubuh dan melakukan kegiatan fisik sehari-hari. Sayuran merupakan bahan pangan sumber vitamin dan mineral dengan kontribusi energi bagi tubuh manusia sebesar $5 \%$ (Hanafie, 2010).

Sayuran memiliki peran dalam program ketahanan pangan nasional. Ketahanan pangan (food security) tidak akan terwujud tanpa ketahanan nutrisi (nutritional security), karena akan berimbas pada kesehatan masyarakat yang semakin menurun. Konsep ketahanan nutrisi ialah menjamin ketersediaan pangan yang bernutrisi dan jumlahnya cukup bagi seluruh lapisan masyarakat. Nutrisi dan keamanan pangan juga merupakan dua hal yang tidak dapat dipisahkan. Jika ketersediaan pangan mengalami kelangkaan, 
maka masyarakat akan mengonsumsi makanan yang berkadar gizi rendah dan tidak aman, dikarenakan bahaya kontaminasi bahan-bahan kimia, mikroba, dan penyakit. Kandungan gizi pada tanaman sayuran semakin dirasakan manfaatnya oleh masyarakat, sehingga ketersediaan sayuran menjadi faktor penting dalam mewujudkan ketahanan pangan dan ketahanan nutrisi nasional (Wulandari et al, 2011).

Tomat, cabai rawit, dan ketimun merupakan jenis sayuran buah yang hampir tidak dapat dipisahkan dari kebutuhan konsumsi harian masyarakat (Sugeng, 2006), karena itu upaya peningkatan produksi ketiga komoditas tersebut secara kuantitas maupun kualitas mutlak diperlukan. Pengembangan budidaya tanaman sayuran telah mendapatkan perhatian dari pemerintah melalui Keputusan Menteri Pertanian Nomor 511/Kpts/PD.310/9/2006 dengan menetapkan sayuran sebagai komoditas binaan Direktorat Jenderal Hortikultura (Pardosi et al, 2014).

Peningkatan produksi tanaman tomat, cabai rawit, dan ketimun sangat ditentukan oleh beberapa faktor, di antaranya penggunaan input berupa pupuk yang berfungsi menambah kandungan unsur hara untuk tetap mempertahankan kesuburan tanah. Kendala yang dihadapi oleh pertanian Indonesia dewasa ini ialah kecenderungan kelangkaan pupuk kimia sintetis atau pupuk anorganik, termasuk pupuk bersubsidi. Harga pupuk yang mahal menyebabkan biaya produksi usahatani meningkat, yang kemudian berimbas pada lonjakan harga produk-produk pertanian.

Penggunaan pupuk anorganik secara berlebihan dan dalam jangka waktu lama menyebabkan menurunnya kualitas kesuburan tanah pertanian. Berdasarkan data dari Pusat Penelitian Tanah dan Agroklimat tahun 2009, sekitar $95 \%$ lahan pertanian di Indonesia mengandung bahan organik kurang dari $1 \%$, padahal batas minimum kadar bahan organik tanah untuk lahan pertanian ialah berkisar antara 4-5\% (Musnamar, 2006). Pemakaian pupuk anorganik berupa Urea dan ZA secara terus menerus dapat menyebabkan menurunnya $\mathrm{pH}$ tanah, menurunkan efisiensi penyerapan unsur $\mathrm{P}$ dan $\mathrm{K}$ oleh tanaman, dan memberikan dampak negatif berupa meningkatnya gangguan hama dan penyakit tanaman (Dibia et al, 2009).

Penggunaan pupuk organik dengan bahan baku yang berasal dari kotoran hewan, hijauan, maupun limbah rumah tangga dapat menjadi alternatif. Bahan-bahan ini umumnya mudah diperoleh dan biaya pengolahan bahan-bahan tersebut menjadi pupuk organik jauh lebih murah. Penggunaan pupuk organik mendukung model pertanian organik yang saat ini banyak dikembangkan untuk mengurangi ketergantungan pemakaian bahan-bahan kimia sintetis pada produksi tanaman yang berdampak negatif terhadap kesehatan konsumen. Teknologi ini juga bersifat lebih ramah lingkungan, karena bertujuan untuk melestarikan kesehatan tanah, tanaman, hewan, manusia, dan ekosistem bumi secara keseluruhan.

Akan tetapi, pemberian pupuk organik yang dilakukan secara langsung tanpa melalui proses pengomposan terlebih dahulu sering menyebabkan tanaman terkena penyakit yang disebabkan oleh bakteri maupun virus, atau tanaman mendadak layu dan mati. Tanpa perlakuan penambahan aktivator berupa mikroorganisme pengurai dapat menyebabkan proses penguraian bahan organik menjadi lama sehingga dibutuhkan waktu yang lama pula untuk diserap oleh tanaman.

Penerapan teknologi Effective Microorganisms (EM4) merupakan solusi untuk meningkatkan kesehatan dan kesuburan tanaman maupun tanah. EM4 mengandung mikroorganisme pengurai yang dapat memfermentasi bahan-bahan organik menjadi senyawa organik yang dapat diserap oleh perakaran tanaman. Salah satu hasil fermentasi bahan organik dengan inokulasi EM4 ialah bokashi. Bokashi memiliki peran penting dalam penyediaan pupuk organik secara cepat untuk memenuhi kebutuhan pupuk pada berbagai jenis tanaman pertanian. Selain itu, EM4 juga dapat dimanfaatkan untuk pembuatan pupuk organik cair. Berbagai macam bahan baku dapat dimanfaatkan untuk pembuatan pupuk organik cair, termasuk limbah rumah tangga berupa air cucian beras. Adapun kelebihan dari pupuk organik cair ialah unsur hara yang dikandungnya lebih cepat tersedia dan mudah diserap oleh akar tanaman.

Bokashi sebagai salah satu bentuk bahan organik berperan sebagai pembenah struktur tanah sehingga menjadi gembur dan menjadi tempat tumbuh yang baik bagi akar tanaman dan organisme tanah yang diperlukan dalam proses penyediaan unsur hara bagi tanaman. Fungsi bokashi padat sebagai penyedia unsur hara bagi tanaman 
bersifat lebih lambat jika dibandingkan dengan pupuk organik cair. Oleh karena itu maka tambahan pasokan unsur hara dari pupuk organik cair sangat diperlukan untuk melengkapi suplai hara ke tanaman yang bersumber dari bokashi berbentuk padat.

Hasil penelitian Pangaribuan et al (2008) menunjukkan bahwa bahan organik berupa bokashi jerami padi dapat memperbaiki pertumbuhan dan produksi buah tomat. Tufaila et al (2014) menyatakan bahwa penggunaan bokashi kotoran ayam dapat meningkatkan produksi tanaman ketimun di tanah masam. Penelitian lainnya yang dilakukan oleh Gustia (2009) memperlihatkan bahwa aplikasi bokashi memberikan peningkatan pada pertumbuhan dan produksi tanaman cabai varietas Inko-99. Sementara itu Elfarisna et al (2014) menyatakan bahwa air limbah cucian beras yang disimpan selama 2 minggu dapat berperan sebagai pengganti pupuk anorganik bagi tanaman anggrek, selada, bayam, kedelai, dan bawang daun.

Berdasarkan hasil-hasil penelitian tersebut, maka diduga kombinasi pemberian bokashi dan air limbah cucian beras sampai pada tingkat tertentu dapat meningkatkan produksi tanaman tomat, cabai rawit, dan ketimun. Hal ini terutama didasarkan pada sifat produksi pertanian yang umumnya memperlihatkan gejala berupa kenaikan hasil yang semakin berkurang (The Law of Diminishing Return) (Suratiyah, 2008). Pemberian input pada mulanya memberikan kenaikan jumlah output yang semakin besar, tetapi sampai batas tertentu maka penambahan jumlah input justru menyebabkan kenaikan output semakin kecil bahkan akan menurun. Di samping itu, setiap tanaman memberikan respon yang berbeda terhadap pemupukan, di antaranya disebabkan karena faktor morfologi tanaman dan aktifitas fisiologi tanaman (Jumin, 2005). Berdasarkan uraian tersebut maka perlu diteliti pengaruh pemberian bokashi dan air limbah cucian beras serta interaksi dari kedua jenis pupuk organik tersebut terhadap produksi tanaman tomat, cabai rawit, dan ketimun.

Tujuan penelitian ini ialah untuk mengetahui a) Perbedaan produksi tomat, cabai rawit, dan ketimun berdasarkan perbedaan konsentrasi pupuk cair yang digunakan, b) Perbedaan produksi tomat, cabai rawit, dan ketimun berdasarkan perbedaan dosis bokashi yang digunakan, dan c) Interaksi antara dosis bokashi dan konsentrasi pupuk cair terhadap produksi tomat, cabai rawit, dan ketimun.

\section{METODE PENELITIAN}

Penelitian ini dilaksanakan pada bulan April hingga Desember 2015 bertempat di Kelurahan Pamona Kecamatan Pamona Puselemba.

Bahan-bahan yang digunakan dalam penelitian ini ialah tanah, jerami padi, kotoran ternak yang telah kering, dedak, arang sekam, limbah sayuran legum, larutan dekomposer EM4, air limbah cucian beras, gula pasir, bibit tanaman tomat, cabai rawit, dan ketimun, polibag, bambu, lirang / kasa plastik, bendrat, tali rafia, karton, dan spidol.

Alat-alat yang digunakan dalam penelitian ini ialah pacul, sekop, parang, ember, terpal, gelas ukur, timbangan, sendok makan, termometer, hand sprayer, dan selang air.

Pembuatan bokashi dilakukan sebagai berikut : a) Bahan-bahan yang disiapkan ialah sebagai berikut: $200 \mathrm{~kg}$ jerami, $50 \mathrm{~kg}$ sisa hijauan, $300 \mathrm{~kg}$ kotoran ternak yang telah kering, $100 \mathrm{~kg}$ dedak, $50 \mathrm{~kg}$ arang sekam, 100 $\mathrm{kg}$ tanah, 1 liter larutan dekomposer (EM4) dan $1 \mathrm{~kg}$ gula pasir, b) Tempat fermentasi yang dipilih ialah yang terlindung dari air hujan dan sengatan matahari langsung, c) Jerami atau hijauan dicacah kecil-kecil, dicampurkan dengan bahan-bahan organik yang telah disiapkan, dan diaduk hingga merata dengan cangkul atau sekop, d) Larutan EM4 diencerkan, diambil 1 liter larutan dan dicampurkan dengan 200 liter air bersih dan 1 kg gula pasir. Larutan disiramkan pada campuran bahan baku sambil diaduk. Kelembaban diatur hingga mencapai $30-40 \%$. Untuk memperkirakan tingkat kelembaban, campuran dikepalkan hingga bisa menggumpal tapi tidak sampai mengeluarkan air. Apabila kelembabannya kurang, ditambahkan air secukupnya. e) Adonan bokashi ditutup dengan plastik atau terpal, dan didiamkan hingga 7-14 hari. Suhu fermentasi dikontrol hingga maksimal $45^{\circ} \mathrm{C}$. Apabila melebihi suhu tersebut, adonan diaduk dengan cangkul agar suhunya turun, dan f) Setelah 710 hari, pupuk bokashi sudah terbentuk dan diaplikasikan secara langsung pada tanaman.

Pembuatan pupuk organik cair air limbah cucian beras dilakukan sebagai berikut : a) Bahan-bahan yang disiapkan ialah sebagai berikut : 10 liter air cucian beras, $1 \mathrm{~kg}$ 
gula pasir, dan 1 liter larutan dekomposer (EM4), b) Bahan-bahan dimasukkan ke dalam ember lalu dicampurkan sampai merata, c) Ember ditutup dengan kain atau kertas untuk menghindari bertelurnya serangga pada campuran tersebut namun tetap bisa ditembus oleh udara atau oksigen, d) Campuran disimpan di tempat yang teduh dan tidak terkena sinar matahari langsung, dan e) Setelah 14 hari, campuran mengeluarkan bau masam, ini menunjukkan bahwa perbanyakan mikroorganisme telah berhasil dan campuran siap diaplikasikan pada tanaman.

Persiapan media tanam dan penanaman dilakukan sebagai berikut : a) Tanah dicangkul, digemburkan, dicampur dengan sekam padi dengan perbandingan 1 : 1, diaduk, kemudian ditambahkan dengan bokashi sesuai perlakuan, b) Campuran tanah dan bokashi dimasukkan ke dalam polibag diameter $35 \mathrm{~cm}, \mathrm{c})$ Benih tomat, cabai rawit, dan ketimun diseleksi, direndam dalam air selama 12 jam, lalu dikeringanginkan. Benih ditanam secara langsung dalam polibag yang berisi media tumbuh.

Perawatan tanaman dan panen dilakukan sebagai berikut : a) Penyiraman dilakukan sesuai kondisi tanaman di lapangan, b) Penyiangan dilakukan terhadap rumput dan tumbuhan liar yang terdapat di sekeliling tanaman, c) Khusus pada tanaman tomat dan ketimun, pada saat umur tanaman mencapai 3 sampai 4 MST dilakukan pengajiran agar batang tanaman menjadi kuat, d) Pengendalian hama dan penyakit tanaman dilakukan sesuai kebutuhan, e) Pupuk cair diberikan saat tanaman berumur 2 MST hingga 6 MST dengan interval seminggu sekali, yaitu dengan cara disiramkan pada tanah di sekeliling tanaman, f) Panen pertama tanaman tomat dan cabai rawit dilakukan setelah tanaman berumur 3 bulan,sedangkan pada tanaman ketimun dilakukan saat tanaman mencapai umur 2 bulan. Panen susulan dilakukan setiap minggu. Buah tomat yang dipanen ialah yang telah tua dan berwarna merah jambu. Buah cabai rawit dapat dipanen bila bentuknya padat dan berwarna merah menyala.

Pemberian bokashi terdiri atas 6 macam perlakuan, yaitu :

$\mathrm{B}_{0}=$ Tanpa bokashi

$\mathrm{B}_{1}=$ Dosis bokashi $100 \mathrm{gr} /$ tanaman

$\mathrm{B}_{2}=$ Dosis bokashi $200 \mathrm{gr} / \mathrm{tanaman}$

$\mathrm{B}_{3}=$ Dosis bokashi $300 \mathrm{gr} /$ tanaman

$\mathrm{B}_{4}=$ Dosis bokashi $400 \mathrm{gr} / \mathrm{tanaman}$
$\mathrm{B}_{5}=$ Dosis bokashi $500 \mathrm{gr} /$ tanaman

Pemberian pupuk organik air limbah cucian beras terdiri atas 5 macam perlakuan, yaitu :

$\mathrm{PC}_{0}=$ Tanpa pupuk cair

$\mathrm{PC}_{1}=$ Konsentrasi $25 \mathrm{ml} / \mathrm{l}$ air/tanaman

$\mathrm{PC}_{2}=$ Konsentrasi $50 \mathrm{ml} / \mathrm{l}$ air/tanaman

$\mathrm{PC}_{3}=$ Konsentrasi $75 \mathrm{ml} / \mathrm{l}$ air/tanaman

$\mathrm{PC}_{4}=$ Konsentrasi $100 \mathrm{ml} / \mathrm{l}$ air/tanaman

Terdapat $6 \times 5=30$ kombinasi

perlakuan, di mana setiap perlakuan diulang sebanyak 2 kali, sehingga diperoleh 60 unit percobaan untuk setiap komoditas tanaman. Dengan demikian untuk ketiga macam komoditas sayuran diperoleh 180 unit percobaan.

Pengamatan dilakukan pada produksi tanaman, yaitu hasil yang diperoleh pada panen pertama hingga 3 minggu sesudahnya. Produksi buah yang diperoleh dari setiap unit percobaan dan ulangannya ditimbang dan dirata-ratakan.

Analisis data yang digunakan dalam penelitian ini ialah analisis varians dua jalan (two way anova), yaitu teknik statistika inferensial parametrik yang digunakan untuk menguji hipotesis komparatif $k$ sampel bila setiap sampel terdiri atas dua kategori atau lebih (Sugiyono, 2009). Apabila hasil analisis menunjukkan bahwa terdapat perbedaan produksi tanaman berdasarkan perbedaan konsentrasi pupuk cair maupun dosis bokashi, atau apabila terjadi interaksi antara kedua perlakuan tersebut maka dilakukan uji lanjutan berupa uji t 2 sampel independen, di mana hasil tanaman pada setiap perlakuan dibandingkan untuk melihat adanya signifikansi perbedaan. Rumus yang digunakan ialah :

$t=\frac{\bar{x}_{1}-\bar{x}_{2}}{\sqrt{\frac{\left(n_{1}-1\right) s_{1}^{2}+\left(n_{2}-1\right) s_{2}^{2}}{n_{1}+n_{2}-2}\left(\frac{1}{n_{1}}+\frac{1}{n_{2}}\right)}}$

(Somantri dan Muhidin, 2006)

\section{HASIL DAN PEMBAHASAN}

\section{Hasil}

Hasil analisis varians untuk pengamatan pada tanaman tomat dapat dilihat pada Tabel 1 sebagai berikut. Hasil analisis varians menunjukkan bahwa tidak terdapat perbedaan produksi tomat berdasarkan perbedaan konsentrasi pupuk cair yang digunakan, terdapat perbedaan produksi tomat 
berdasarkan perbedaan dosis bokashi yang digunakan, dan tidak terdapat interaksi antara dosis bokashi dan konsentrasi pupuk cair terhadap produksi tomat.

Tabel 1. Tabel Ringkasan Anova

\begin{tabular}{|c|c|c|c|c|c|}
\hline Sumber Variasi & $\mathrm{dk}$ & JK & MK & F hit & $\mathrm{F}$ tab \\
\hline Antar Kolom & 4 & 24843,89 & 6210,97 & $1,01^{\text {tn }}$ & 2,69 \\
\hline Antar Baris & 5 & 162598,00 & 32519,60 & 5,29 * & 2,53 \\
\hline Interaksi & 20 & 143316,51 & 7165,83 & $1,17^{\mathrm{tn}}$ & 1,93 \\
\hline Dalam & 30 & 184313,00 & 6143,77 & & \\
\hline Total & 59 & 515071,40 & & . & \\
\hline
\end{tabular}

Keterangan : * = berpengaruh nyata pada taraf signifikansi $5 \%$

tn $=$ tidak berpengaruh nyata pada taraf signifikansi $5 \%$

Karena terdapat perbedaan produksi tomat berdasarkan perbedaan dosis bokashi yang digunakan, maka perlu dilakukan uji lanjutan berupa uji t 2 sampel independen untuk

Tabel 5. Hubungan Antara Dosis Bokashi dengan Produksi Tomat

\begin{tabular}{cc}
\hline Dosis Bokashi (gr) & $\begin{array}{c}\text { Rata-rata Produksi Tomat } \\
\text { (gr) }\end{array}$ \\
\hline 0 & $148,90^{\mathrm{a}}$ \\
\hline 100 & $185,30^{\mathrm{b}}$ \\
\hline 200 & $243,60^{\mathrm{c}}$ \\
\hline 300 & $250,40^{\mathrm{c}}$ \\
\hline 400 & $231,00^{\mathrm{d}}$ \\
\hline 500 & $314,20^{\mathrm{e}}$ \\
\hline
\end{tabular}

Keterangan : Angka-angka yang diikuti huruf yang sama tidak berbeda nyata pada taraf signifikansi $5 \%$

Hasil analisis varians untuk pengamatan pada tanaman cabai rawit dapat dilihat pada Tabel 3 sebagai berikut. Hasil analisis varians menunjukkan bahwa terdapat perbedaan produksi cabai rawit berdasarkan perbedaan konsentrasi pupuk cair yang digunakan,

terdapat perbedaan produksi cabai rawit berdasarkan perbedaan dosis bokashi yang digunakan, dan tidak terdapat interaksi antara dosis bokashi dan konsentrasi pupuk cair terhadap produksi cabai rawit.

Tabel 3. Tabel Ringkasan Anova

\begin{tabular}{|c|c|c|c|c|c|}
\hline Sumber Variasi & $\mathrm{dk}$ & $\mathrm{JK}$ & MK & F hit & $\mathrm{F} \mathrm{tab}$ \\
\hline Antar Kolom & 4 & 575,35 & 143,84 & $2,93^{*}$ & 2,69 \\
\hline Antar Baris & 5 & 1253,77 & 250,75 & $5,12^{*}$ & 2,53 \\
\hline Interaksi & 20 & 1800,56 & 90,03 & $1,83^{\text {tn }}$ & 1,93 \\
\hline Dalam & 30 & 1470,47 & 49,02 & & \\
\hline Total & 59 & 5100,15 & & & \\
\hline
\end{tabular}

Keterangan : * = berpengaruh nyata pada taraf signifikansi $5 \%$ tn $=$ tidak berpengaruh nyata pada taraf signifikansi $5 \%$ 
Karena terdapat perbedaan produksi cabai rawit berdasarkan perbedaan konsentrasi pupuk cair dan dosis bokashi yang digunakan, maka perlu dilakukan uji lanjutan berupa uji t 2 sampel independen untuk mengetahui perbedaan produksi antara setiap perlakuan. Adapun hasil uji lanjutan ialah sebagai berikut :

Tabel 4. Hubungan Antara Konsentrasi Pupuk Cair dengan Produksi Cabai Rawit

\begin{tabular}{cr}
\hline $\begin{array}{c}\text { Konsentrasi Pupuk Cair } \\
(\mathrm{ml})\end{array}$ & $\begin{array}{r}\text { Rata-rata Produksi Cabai Rawit } \\
(\mathrm{gr})\end{array}$ \\
\hline 0 & $29,11^{\mathrm{a}}$ \\
\hline 25 & $35,98^{\mathrm{b}}$ \\
\hline 50 & $31,19^{\mathrm{ac}}$ \\
\hline 75 & $30,82^{\mathrm{ac}}$ \\
\hline 100 & $27,05^{\mathrm{ad}}$ \\
\hline
\end{tabular}

Keterangan : Angka-angka yang diikuti huruf yang sama tidak berbeda nyata pada taraf signifikansi $5 \%$

Tabel 5. Hubungan Antara Dosis Bokashi dengan Produksi Cabai Rawit

\begin{tabular}{cc}
\hline $\begin{array}{c}\text { Dosis Bokashi } \\
(\mathrm{gr})\end{array}$ & $\begin{array}{c}\text { Rata-rata Produksi Cabai Rawit } \\
(\mathrm{gr})\end{array}$ \\
\hline 0 & $29,99^{\mathrm{a}}$ \\
\hline 100 & $34,39^{\mathrm{b}}$ \\
\hline 200 & $38,33^{\mathrm{c}}$ \\
\hline 300 & $33,34^{\mathrm{b}}$ \\
\hline 400 & $26,22^{\mathrm{d}}$ \\
\hline 500 & $25,40^{\mathrm{d}}$ \\
\hline
\end{tabular}

Keterangan : Angka-angka yang diikuti huruf yang sama tidak berbeda nyata pada taraf signifikansi $5 \%$

Hasil analisis varians untuk pengamatan pada tanaman ketimun dapat dilihat pada Tabel 6 sebagai berikut. Hasil analisis varians menunjukkan bahwa terdapat perbedaan produksi ketimun berdasarkan perbedaan konsentrasi pupuk cair yang

Tabel 6. Tabel Ringkasan Anova digunakan, terdapat perbedaan produksi ketimun berdasarkan perbedaan dosis bokashi yang digunakan, dan terdapat interaksi antara dosis bokashi dan konsentrasi pupuk cair terhadap produksi buah ketimun.

\begin{tabular}{|c|c|c|c|c|c|}
\hline Sumber Variasi & $\mathrm{dk}$ & JK & MK & F hit & $\mathrm{F}$ tab \\
\hline Antar Kolom & 4 & 111713,432 & 27928,358 & $29,215^{\star}$ & 2,69 \\
\hline Antar Baris & 5 & 34619,750 & 6923,950 & $7,243^{*}$ & 2,53 \\
\hline Interaksi & 20 & 38858,668 & 1942,933 & $2,032^{*}$ & 1,93 \\
\hline Dalam & 30 & 28679,000 & 955,967 & & \\
\hline Total & 59 & 213870,850 & & & \\
\hline
\end{tabular}

Keterangan : * $=$ berpengaruh nyata pada taraf signifikansi $5 \%$

Karena terdapat perbedaan produksi ketimun berdasarkan perbedaan konsentrasi pupuk cair dan dosis bokashi yang digunakan, maka perlu dilakukan uji lanjutan berupa uji t 2 sampel independen untuk mengetahui perbedaan produksi antara setiap perlakuan. Adapun hasil uji lanjutan ialah sebagai berikut : 
Tabel 7. Hubungan Antara Konsentrasi Pupuk Cair dengan Produksi Ketimun

\begin{tabular}{crr}
\hline Konsentrasi Pupuk Cair $(\mathrm{ml})$ & \multicolumn{2}{c}{ Rata-rata Produksi Buah Ketimun } \\
$(\mathrm{gr})$ & \\
\hline 0 & $533,75^{\mathrm{a}}$ \\
\hline 25 & $615,42^{\mathrm{b}}$ \\
\hline 50 & $509,42^{\mathrm{c}}$ \\
\hline 75 & $493,33^{\mathrm{d}}$ \\
\hline 100 & $513,33^{\mathrm{c}}$ \\
\hline
\end{tabular}

Keterangan : Angka-angka yang diikuti huruf yang sama tidak berbeda nyata pada taraf signifikansi $5 \%$

Tabel 8. Hubungan Antara Dosis Bokashi dengan Produksi Ketimun

\begin{tabular}{cr}
\hline Dosis Bokashi (gr) & \multicolumn{2}{c}{ Rata-rata Produksi Buah Ketimun } \\
$(\mathrm{gr})$ & \\
\hline 0 & $490,00^{\mathrm{a}}$ \\
\hline 100 & $514,00^{\mathrm{b}}$ \\
\hline 200 & $538,00^{\mathrm{c}}$ \\
\hline 300 & $547,30^{\mathrm{d}}$ \\
\hline 400 & $547,50^{\mathrm{d}}$ \\
\hline 500 & $561,50^{\mathrm{e}}$ \\
\hline
\end{tabular}

Keterangan : Angka-angka yang diikuti huruf yang sama tidak berbeda nyata pada taraf signifikansi $5 \%$

\section{Pembahasan}

Hasil penelitian menunjukkan bahwa pemberian bokashi berpengaruh nyata terhadap produksi ketiga jenis tanaman sayuran. Pada tanaman tomat, pemberian bokashi dengan dosis 500 gram per tanaman menghasilkan rata-rata produksi tomat tertinggi sebesar 314,20 gram. Hasil ini berbeda nyata dengan keempat perlakuan lainnya. Pada tanaman cabai rawit, rata-rata produksi tertinggi diperoleh pada pemberian bokashi dengan dosis 200 gram per tanaman, yaitu sebesar 38,33 gram. Rata-rata produksi tersebut berbeda nyata dengan kelima perlakuan lainnya. Pada tanaman ketimun, penggunaan bokashi dengan dosis 500 gram per tanaman memberikan rata-rata produksi tertinggi sebesar 561,50 gram, berbeda nyata dengan kelima perlakuan lainnya.

Data-data tersebut memperlihatkan bahwa ketiga jenis sayuran memberikan respon yang berbeda terhadap penggunaan bokashi. Pada tanaman cabai rawit, dosis bokashi sebesar 200 gram sudah mampu memenuhi kebutuhan tanaman akan unsur hara sehingga dapat bertumbuh dan berproduksi secara optimal. Tetapi pada tanaman tomat dan ketimun, diperlukan dosis bokashi yang lebih besar guna terpenuhinya kebutuhan unsur hara bagi tanaman.

Pada tanaman cabai rawit, peningkatan dosis bokashi mampu memperbesar produksi sampai pada titik maksimum, tetapi selanjutnya penambahan dosis justru menyebabkan menurunnya produksi tanaman. Hal ini mengindikasikan adanya Hukum Kenaikan Hasil Yang Semakin Berkurang (The Law of Diminishing Return), yaitu gejala penurunan jumlah output yang dihasilkan sebagai akibat penambahan kuantitas input yang digunakan. Gejala ini tidak ditemukan pada tanaman tomat dan ketimun, karena dosis bokashi terbesar (500 gram per tanaman) justru memberikan produksi maksimum. Pada tanaman tomat dan ketimun, hubungan antara dosis bokashi dengan produksi bersifat linear. Pengaruh pemberian bokashi terhadap produksi ketiga jenis tanaman dapat digambarkan sebagai berikut. 


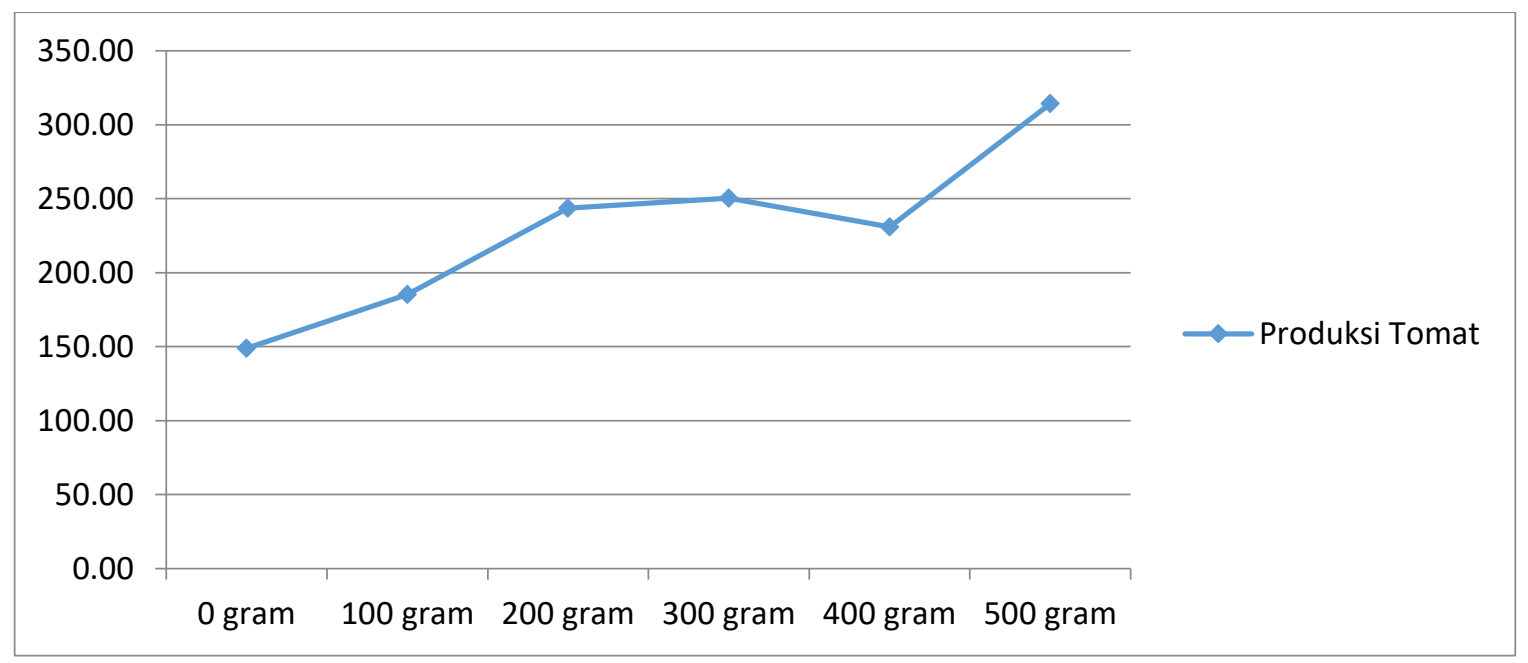

Gambar 1. Pengaruh Pemberian Bokashi Terhadap Produksi Tomat

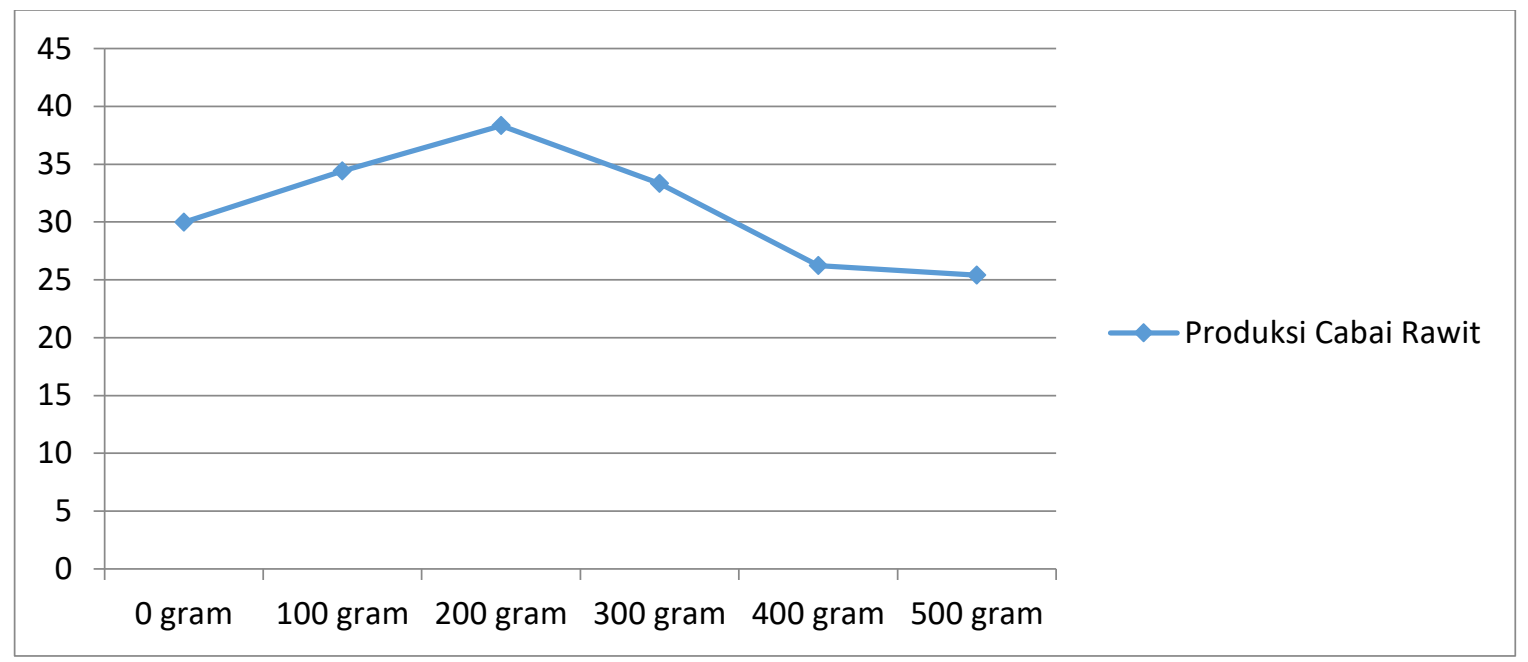

Gambar 2. Pengaruh Pemberian Bokashi Terhadap Produksi Cabai Rawit

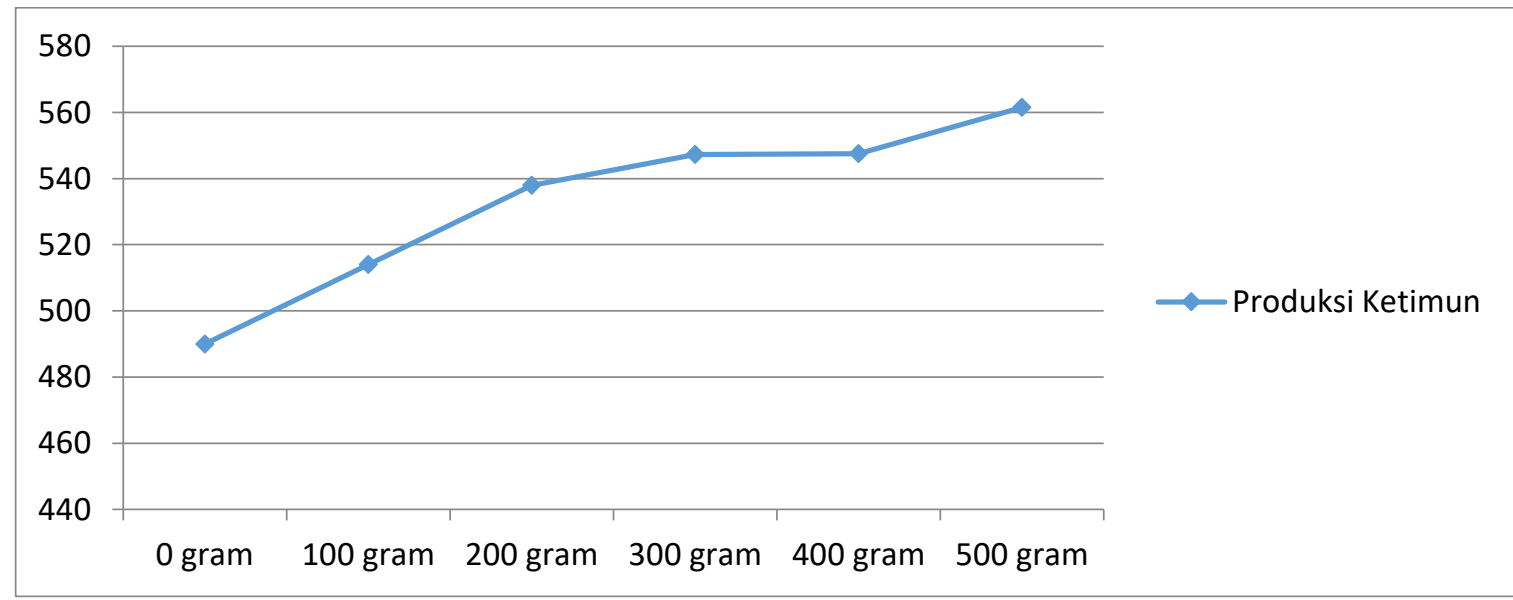

Gambar 3. Pengaruh Pemberian Bokashi Terhadap Produksi Ketimun

Pemberian bokashi menyebabkan struktur tanah menjadi lebih remah dan gembur, sehingga menjadi media yang sangat baik bagi pertumbuhan dan perkembangan 
akar tanaman. Selain itu, kandungan unsur hara yang terdapat dalam bokashi lebih cepat terurai dan mudah terserap oleh akar tanaman. Penyerapan unsur hara secara optimal oleh akar tanaman menyebabkan terpenuhinya kebutuhan unsur hara tanaman yang sangat diperlukan bagi proses pertumbuhan hingga pembentukan buah pada tanaman (Dibia et al, 2009).

Bahan-bahan dasar pembuatan bokashi di antaranya ialah sisa hijauan legum, dalam hal ini tanaman kacang tanah dan kedelai, serta kotoran ternak. Menurut Jumin (2005), hijauan yang digunakan sebagai pupuk organik berfungsi menambah daya retensi air pada tanah, meningkatkan kapasitas tukar kation, mengurangi bahaya tercucinya unsurunsur hara dari tanah (leaching), meningkatkan kandungan unsur hara mikro seperti nitrogen dan fosfor, serta pembentukan struktur tanah menjadi lebih remah. Lebih lanjut Jumin (2005) juga menyatakan bahwa kotoran ternak sebagai pupuk organik berfungsi untuk memperbaiki kesuburan fisik tanah melalui perbaikan struktur dan permeabilitas tanah, meningkatkan aktivitas mikroorganisme tanah yang berarti meningkatkan kesuburan biologis tanah, serta dihasilkannya hormon yang menstimulir pertumbuhan tanaman seperti auxin, gibberelin, dan sitokinin pada proses dekomposisi bahan-bahan organik.
Berdasarkan hasil penelitian diketahui bahwa pemberian pupuk cair air limbah cucian beras berpengaruh nyata terhadap produksi tanaman cabai rawit dan ketimun, tetapi tidak berpengaruh nyata terhadap produksi tanaman tomat. Hal ini mengindikasikan bahwa tanaman tomat tidak responsif terhadap pemberian pupuk cair air cucian beras. Pada tanaman cabai rawit, konsentrasi pupuk cair sebesar 25 ml/tanaman memberikan rata-rata produksi tertinggi sebesar 35,98 gram, berbeda nyata dengan keempat perlakuan lainnya. Demikian pula pada tanaman ketimun, konsentrasi pupuk cair $25 \mathrm{ml} /$ tanaman menghasilkan rata-rata produksi tertinggi sebesar 615,42 gram yang berbeda nyata dengan perlakuan-perlakuan lainnya.

Konsentrasi pupuk cair $25 \mathrm{ml} /$ tanaman merupakan konsentrasi maksimum sebab peningkatan konsentrasi pupuk cair selanjutnya pada umumnya cenderung menurunkan produksi tanaman hingga pada taraf yang lebih kecil daripada kontrol. Pengaruh pemberian pupuk cair air limbah cucian beras terhadap produksi tanaman cabai rawit dan ketimun dapat digambarkan sebagai berikut.

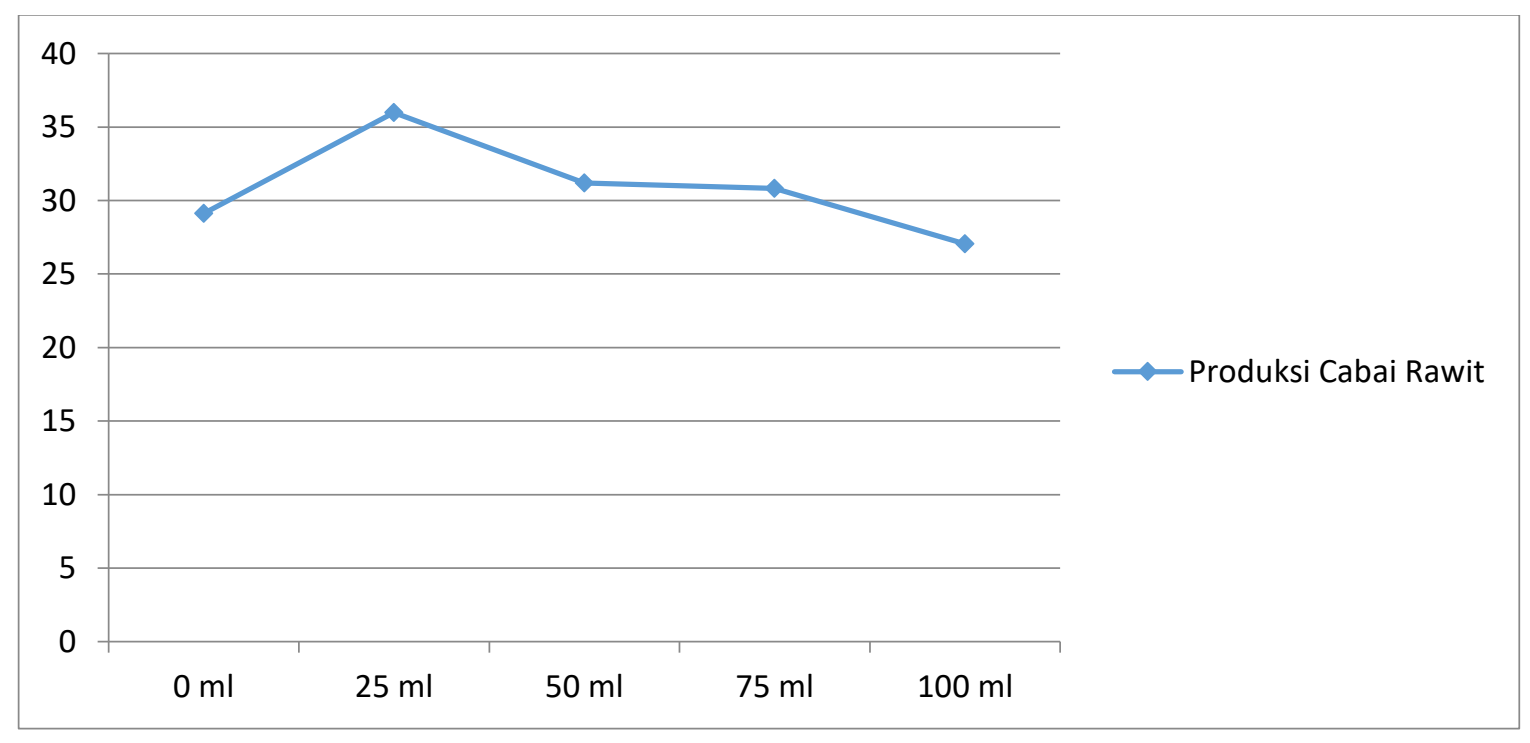

Gambar 4. Pengaruh Pemberian Pupuk Cair Terhadap Produksi Cabai Rawit 


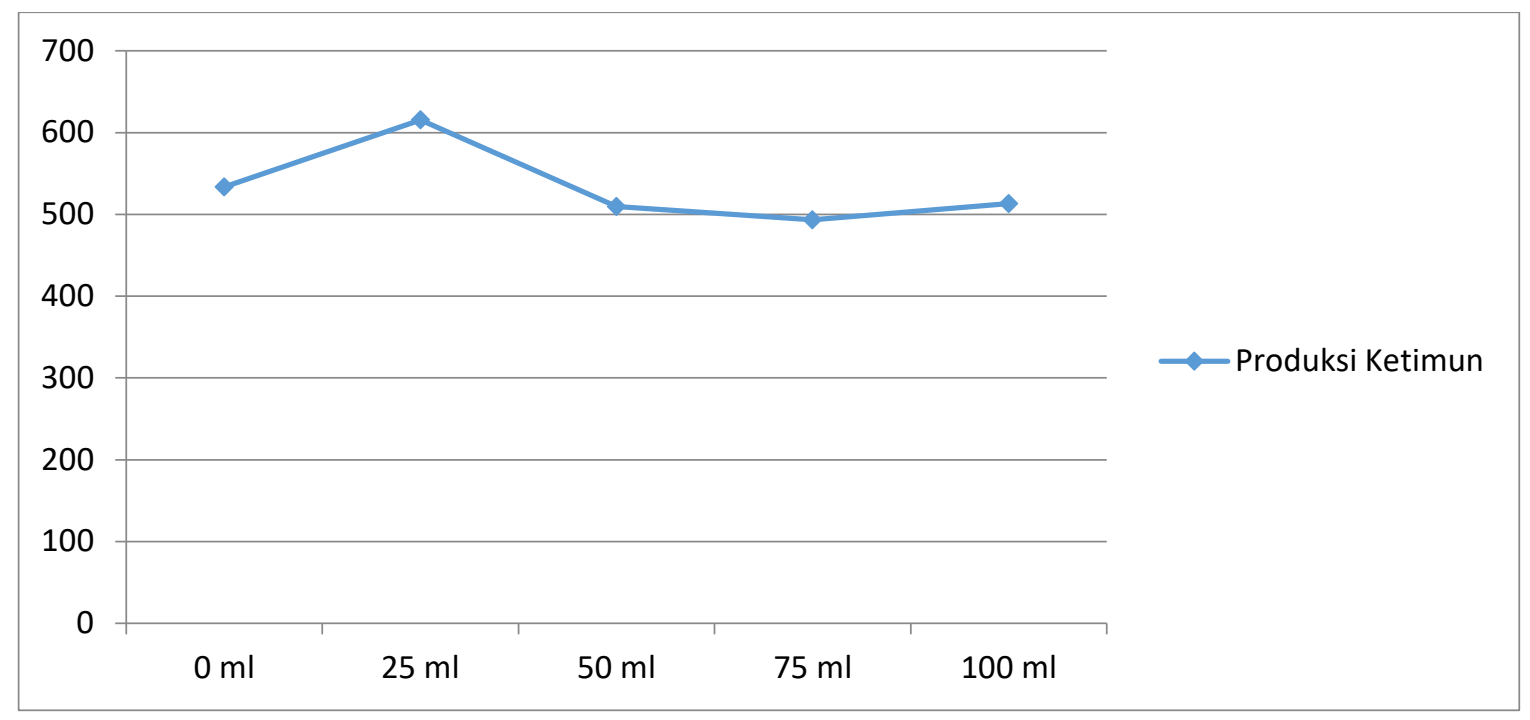

Gambar 5. Pengaruh Pemberian Pupuk Cair Terhadap Produksi Ketimun

Menurut Wulandari (2011), kandungan unsur hara yang dominan terdapat di dalam air limbah cucian beras ialah nitrogen, fosfor, kalium, kalsium, dan magnesium. Nitrogen $(\mathrm{N})$ berperan dalam pertumbuhan vegetatif tanaman, terutama pembentukan daun, tunas, dan penambahan tinggi tanaman. Fosfor $(P)$ merupakan penyusun asam amino yang diperlukan bagi pembelahan sel guna merangsang pembungaan dan pembentukan biji. Kalium (K) berperan mempertinggi sifat vigor pada tanaman, memperbaiki perakaran, serta mengaktifkan pembentukan klorofil. Kalsium (Ca) merupakan penyusun dinding sel, dan berperan dalam pemeliharaan integritas sel dan permeabilitas membran. Magnesium (Mg) merupakan unsur esensial penyusun klorofil serta berperan dalam proses sintesis protein pada tanaman.

Selain itu, kandungan vitamin B1 pada air limbah cucian beras mampu mengoptimalkan pertumbuhan perakaran tanaman. Wulandari (2011) mengemukakan bahwa akar merupakan bagian utama dari organ tanaman yang memasok air, mineral, dan unsur hara yang penting ke bagian tajuk tanaman untuk pertumbuhan dan perkembangan tanaman.

Kondisi air cucian beras yang tidak pekat (encer) menyebabkan viskositas cairan rendah sehingga tanaman, secara khusus bagian akar, lebih mudah mengabsorbsi unsur hara yang terdapat dalam air cucian beras tersebut. Unsur hara yang terabsorbsi kemudian disalurkan dan digunakan untuk pertumbuhan dan perkembangan akar, demikian pula kandungan fotosintat yang ditranslokasikan ke bagian tajuk tanaman (Elfarisna, 2014).

Peningkatan konsentrasi pupuk cair , terutama pada konsentrasi di atas 25 $\mathrm{ml} /$ tanaman diduga menyebabkan tanah berada pada kondisi jenuh akan unsur hara. Menurut Jumin (2005), efisiensi pemupukan merupakan rasio antara jumlah unsur pupuk yang dapat diabsorbsi tanaman dengan jumlah unsur pupuk yang diberikan. Kelebihan pemberian pupuk secara kuantitas dibandingkan dengan kebutuhan serapan unsur hara oleh tanaman dapat menyebabkan inefisiensi serta berdampak negatif pada pertumbuhan tanaman.

Hasil analisis varians menunjukkan bahwa tidak terjadi interaksi antara pemberian bokashi dan air limbah cucian beras terhadap produksi tanaman tomat dan cabai rawit, tetapi terjadi interaksi antara kedua jenis pupuk tersebut terhadap produksi tanaman ketimun. Adanya interaksi tersebut dapat dilihat melalui Gambar 6 sebagai berikut. 


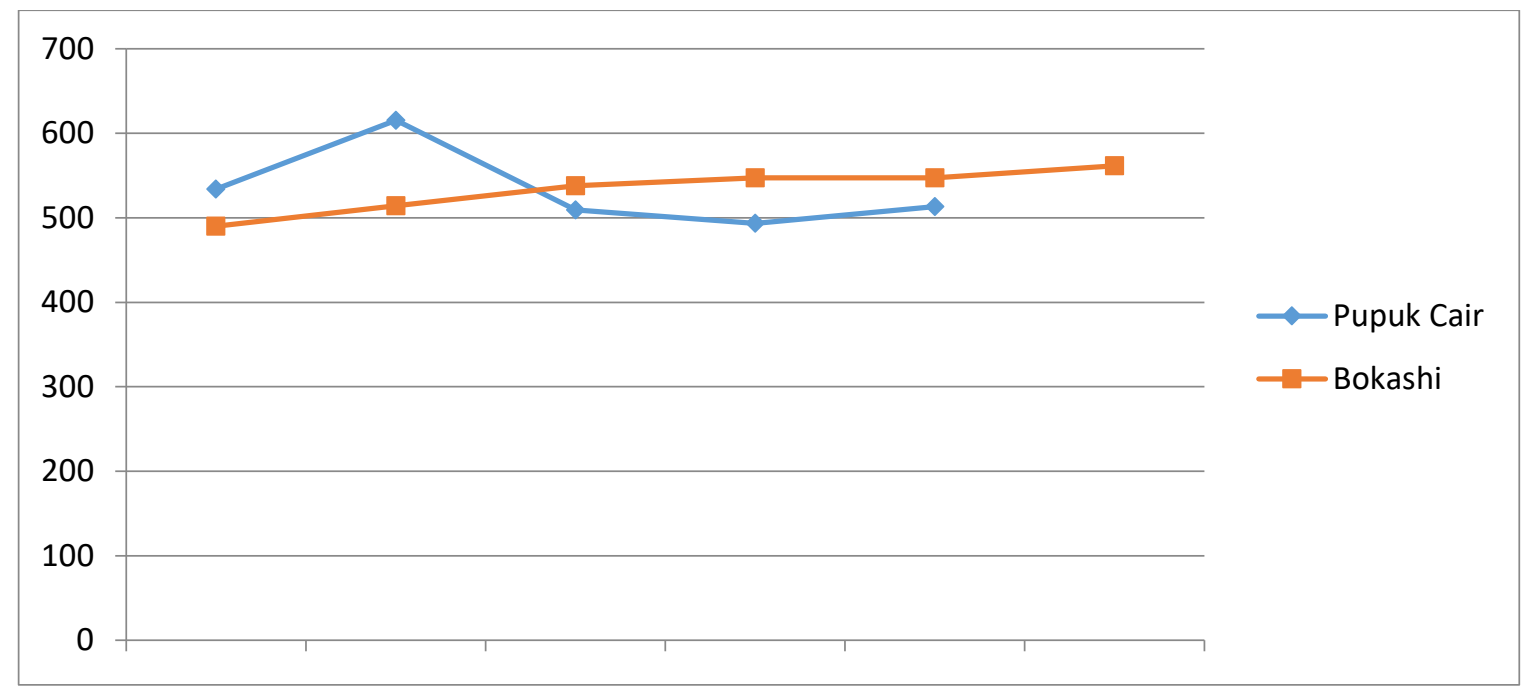

Gambar 6. Interaksi Bokashi dan Pupuk Cair Terhadap Produksi Ketimun

Menurut Sugiyono (2009), interaksi terjadi jika perubahan variabel independen menyebabkan variabel dependen pada salah satu sampel meningkat, sedangkan variabel dependen pada sampel lainnya menurun. Dengan demikian interaksi terjadi jika peningkatan rata-rata produksi buah hanya disebabkan oleh peningkatan salah satu input pupuk yang digunakan, karena ada input pupuk yang jika kuantitasnya ditingkatkan justru akan menyebabkan penurunan produksi.

Pada gambar terlihat bahwa peningkatan pemberian dosis bokashi yang menyebabkan peningkatan produksi ketimun tidak dibarengi dengan peningkatan produksi ketimun karena bertambahnya konsentrasi pupuk cair. Pada perlakuan pemberian bokashi, garis trend menunjukkan peningkatan produksi buah ketimun seiring dengan peningkatan dosis bokashi yang diaplikasikan pada tanaman. Tetapi pada pemberian pupuk cair air limbah cucian beras, garis trend menunjukkan kenaikan produksi tanaman pada konsentrasi pupuk cair $25 \mathrm{ml} / \mathrm{tanaman}$, tetapi kemudian terjadi penurunan produksi jika konsentrasi pupuk cair ditingkatkan lebih dari $25 \mathrm{ml} /$ tanaman. Dengan demikian terlihat bahwa interaksi yang negatif terjadi pada penggunaan bokashi dan pupuk cair air cucian beras terhadap produksi ketimun, yaitu pada konsentrasi pupuk cair sebesar 25 $\mathrm{ml} /$ tanaman.

Adanya interaksi negatif menunjukkan bahwa tanaman ketimun sensitif terhadap peningkatan pemberian dosis atau konsentrasi pupuk. Kejenuhan tanah dengan unsur hara yang berasal dari bokashi maupun pupuk cair air cucian beras menyebabkan absorbsi unsur hara secara berlebih ke dalam tubuh tanaman dan berdampak negatif terhadap pertumbuhan dan produksi tanaman. Efisiensi pemupukan pada tanaman ketimun tercapai bila dosis bokashi yang diaplikasikan sebanyak 500 gram per tanaman dan dikombinasikan dengan pupuk cair air limbah cucian beras dengan konsentrasi yang tidak melebihi 25 $\mathrm{ml} /$ tanaman.

\section{KESIMPULAN DAN SARAN}

\section{Kesimpulan}

1. Pemberian pupuk cair air limbah cucian beras berpengaruh secara signifikan terhadap produksi cabai rawit dan ketimun. Konsentrasi maksimum pupuk cair sebesar $25 \mathrm{ml} /$ tanaman memberikan produksi tertinggi, tetapi peningkatan konsentrasi di atas $25 \mathrm{ml}$ menurunkan produksi tanaman.

2. Pemberian bokashi berpengaruh secara signifikan terhadap produksi tomat, cabai rawit, dan ketimun. Pada tanaman tomat dan ketimun terdapat hubungan yang linear antara dosis bokashi dengan produksi tanaman, di mana dosis sebesar 500 gram per tanaman memberikan produksi tertinggi. Pada tanaman cabai rawit dosis bokashi 200 gram per tanaman memberikan produksi tertinggi, tetapi peningkatan dosis di atas 200 gram menurunkan produksi tanaman.

3. Terdapat interaksi antara dosis bokashi dan konsentrasi pupuk cair air limbah cucian beras terhadap produksi tanaman ketimun. Interaksi negatif terjadi ketika 
peningkatan dosis bokashi yang menyebabkan peningkatan produksi ketimun tidak simultan dengan peningkatan konsentrasi pupuk cair yang justru menyebabkan penurunan produksi tanaman.

\section{Saran}

Pada penelitian sejenis sebaiknya dilengkapi dengan analisis kandungan hara tanah sebelum dan sesudah perlakuan aplikasi pupuk, maupun analisis kandungan hara yang terdapat di dalam pupuk. Dengan demikian dapat diperoleh keterangan mengenai perubahan kandungan hara sebagai dampak dari pemberian .pupuk pada tanah.

\section{UCAPAN TERIMA KASIH}

Ucapan terima kasih disampaikan kepada Lembaga Penelitian dan Pengabdian kepada Masyarakat (LPPM) Unkrit, secara khusus kepada Bapak Yunober Mberato, S.P.,M.P. selaku Ketua LPPM atas dukungan dana bagi penelitian ini. Terima kasih kepada mahasiswa Fakultas Pertanian Unkrit yang telah memberikan bantuan tenaga pada beberapa pekerjaan teknis dalam penelitian ini.

\section{DAFTAR PUSTAKA}

Dibia, I.Ny., M.D. Dana, M.D. Trigunasih, T. Kusmawati, dan M.D.S. Sumarniasih, 2009. Pembuatan Kompos Bokashi dari Limbah Pertanian dengan Menggunakan Aktivator EM4 di Desa Megati Tabanan. Lembaga Pengabdian kepada Masyarakat Universitas Udayana. Denpasar.

Elfarisna, 2014. Pengaruh Metode Pelatihan dan Pengetahuan tentang Limbah Organik terhadap Keterampilan Petani Membuat Pupuk Organik. Jurnal IImiah Pendidikan Lingkungan dan Pembangunan Berkelanjutan Volume 13 Nomor 2 Tahun 2014.

Elfarisna, R.T. Puspitasari, Y. Suryati, dan N.T. Pradana, 2014. Isolasi Mikroba yang Dapat Menghilangkan Bau pada Pupuk Organik Air Limbah Cucian Beras. Jurnal Matematika, Sains, dan Teknologi
Volume 15 Nomor 2 Tahun 2014 Halaman 91-96.

Fitria, Y., 2008. Pembuatan Pupuk Organik Cair dari Limbah Cair Industri Perikanan Menggunakan Asam Asetat dan EM4 (Effective Microorganisms 4). Tugas Akhir. Fakultas Perikanan dan Kelautan Institut Pertanian Bogor. Bogor.

Gustia, H., 2009. Pengaruh Pemberian Bokashi terhadap Pertumbuhan dan Produksi Tanaman Cabe var. Inko-99. Jurnal Agrosia Volume 12 Nomor 2 Tahun 2009 Halaman 113-123.

Hanafie, R., 2010. Pengantar Ekonomi Pertanian. Andi Offset. Yogyakarta.

Jumin, H.B., 2005. Dasar-dasar Agronomi. Rajawali Press. Jakarta.

Musnamar, E.I., 2009. Pembuatan dan Aplikasi Pupuk Organik Padat (Seri Agro Tekno). Penebar Swadaya. Jakarta.

Pangaribuan, D. dan H. Pujisiswanto, 2008. Pemanfaatan Kompos Jerami untuk Meningkatkan Produksi dan Kualitas Buah Tomat. Prosiding Seminar Nasional Sains dan Teknologi II Universitas Lampung. Bandar Lampung.

Pardosi, A.H., Irianto, dan Mukhsin, 2014. Respon Tanaman Sawi terhadap Pupuk Organik Cair Limbah Sayuran pada Lahan Kering Utisol. Prosiding Seminar Nasional Lahan Suboptimal 2104. Palembang.

Somantri, A. dan S.A. Muhidin, 2006. Aplikasi Statistika dalam Penelitian. Pustaka Setia. Bandung.

Sugeng, H.R., 2006. Bercocok Tanam Sayuran. Aneka Ilmu. Semarang.

Sugiyono, 2009. Statistika untuk Penelitian. Alfabeta. Bandung.

Suratiyah, K., 2008. IImu Usahatani. Penebar Swadaya. Jakarta.

Suryati, Y., 2008. Respon Tanaman Anggrek Bulan terhadap Jenis Media Tanam dan Pemupukan pada Sistem Pertanian 
Organik. Jurnal Penelitian UMJ Volume 14 Nomor 1 Tahun 2008.

Tufaila, M., D.D. Laksana, dan S. Alam, 2014. Aplikasi Kompos Kotoran Ayam untuk Meningkatkan Hasil Tanaman Mentimun (Cucumis sativus L.) di Tanah Masam. Jurnal Agroteknos Volume 4 Nomor 2 Tahun 2014 Halaman 119-126.

Wulandari, C., 2011. Pengaruh Air Cucian Beras Merah dan Beras Putih terhadap
Pertumbuhan dan Hasil Selada (Lactuca sativa L.). Skripsi. Fakultas Pertanian Universitas Gadjah Mada. Yogyakarta.

Zulyana, U., 2011. Respon Ketimun (Cucumis sativus L.) terhadap Pemberian Kombinasi Dosis dan Macam Bentuk Pupuk Kotoran Sapi di Getasan. Skripsi. Fakultas Pertanian Universitas Sebelas Maret. Surakarta. 